\title{
3 To win both the battle and the war
}

\author{
Judicial determination of property \\ rights of spouses in Ghana
}

\author{
Maame Yaa Mensa-Bonsu and Maame A.S. \\ Mensa-Bonsu
}

\section{Introduction}

Customary law has long been problematic for wives seeking access to marital property in Ghana. In both matrilineal and patrilineal family systems, marriage does not entail the self-acquired estates of the spouses (Mensa-Bonsu, 2012). The self-acquired property, therefore, became family property on the intestate death of the owner, leaving the surviving spouse without an interest in the property which they should rightfully own. The cultural bias in favor of males in succession and other customary laws have served to widen the economic chasm between males and females, with the latter often unable to enjoy the products of their labor. From pre-independence times until the 1992 constitution, Ghanaian courts determined disputes involving marital property largely under customary law, which, as noted, is often disadvantageous to wives. What progress was made toward parity resulted from judges' reliance on their own culturally shaped notions of fairness, and standards of progressive thinking. The 1992 Constitution of Ghana has provided Ghana's legal order with a new and apparently more just standard for the distribution of marital property. This chapter evaluates seminal cases from before and since 1992 to establish the practical impact of Article 22 of the 1992 constitution on the financial fortunes of ex-wives (i.e., widowed or divorced). We seek to answer the following questions:

1. Have judicial outcomes improved for women since the 1992 constitution took over the regulation of spousal property rights?

2. Has the rhetoric of judicial law-making in fact evolved along the lines of the 1992 constitution?

The chapter is divided into three sections. The first briefly examines the state of Ghana's law prior to the coming into force of the 1992 constitution. It outlines the customary law position and the judicial efforts at progressing beyond this position through the substantial contribution doctrine, statute law, and the application of equitable principles. The second provides an extensive review of the trends in the outcomes and rhetoric since 1993, when the constitution came

DOI: $10.4324 / 9780429327865-4$ 
into force. Of particular interest is the import of Article 22 on the judicial determination of spousal rights to marital property. Finally, we consider the challenges posed by judicial interpretation of the relevant provisions and caveats applied by subsequent courts. We provide a critical analysis of the potential tensions between Article 22 and other constitutional provisions. While not proposing specific reforms, the insights this chapter will achieve are critical for accurately assessing the progress we have made toward creating a just and equitable society and how much remains to be done. We advance these arguments with the goal that they will contribute to the evolution of Ghana into a consciously shaped, rather than reactionary, society, with the full intent to advance the rights of women.

\section{Property rights of wives: Before 1992}

This section provides an overview of the state of the law up until the 1992 constitution entered into force by looking first at the outcomes and then at the rhetoric under which the said outcomes were achieved. The goal is to contextualize any changes that the 1992 constitution has achieved in respect of both the guiding principles for the distribution of property between spouses upon the dissolution or determination of marriage, and the portions of the estate that have typically fallen to the female spouse. We do this by examining the landmark cases from Ghana's independence in 1957 until December 1992, when the last dictatorship ended.

\section{Judicial rhetoric}

The rhetoric of the pre-1992 regime on spousal rights was centered on three things: customary law, equity, and statute law. In that era, both the rhetoric and consequent outcomes were based exclusively on customary law. The experience of ex-wives and widows was especially dire under these laws, leading to court-led initiatives to soften the impact of customary law on them. But as the court would not depart too far from the customary law rule, the improvement was not overwhelming. The statutory interventions, though helpful, did not apply to every ex-wife/widow in every circumstance (Watnizek, 1991). Equity was also sometimes invoked to provide relief in particularly unjust situations. However, customary and statute law could not be entirely sidestepped. Equity could, therefore, not serve as a wholesale rectifier of the harsh impact of customary law and statute law. Thus, the situation until the 1992 constitution entered into force was one of inconsistencies and inequality for wives. We now examine briefly how women fared in terms of outcomes under each of these three sources of judicial rhetoric.

\section{Customary law}

The decision in Quartey v. Martey (1959) set out the judicial understanding of customary law in respect of the property rights of widows. In that case, the 
plaintiff, who had been married to the intestate under customary law for over 25 years, sued her deceased husband's family for expenses incurred in the course of the funeral and for a one-third share in his estate. She argued that as she had assisted her late husband both in his work and financially, and as he had by such assistance acquired the properties, she was entitled to a share thereof.

Ollennu J held that by customary law, it was the duty of a man's wife and children to assist him in carrying out the duties of his station in life. The proceeds of that joint effort, and any property acquired with such proceeds, were by customary law the property of the man and not the joint property of the spouses. ${ }^{1}$ The only right of a widow, the court further held, was to maintenance and support from the family of her deceased husband. Unsupported by evidence (Daniels, 1972), Quartey v Martey nevertheless became firmly entrenched in the jurisprudence and was followed in a long line of cases, including Yaotey v. Quaye (1961), Adom v Kwarley (1962), Manu v. Kuma (1963), and Jonas v. Ofori (1988). Ayer v. Kumordzie (1964) held that even the chattels a husband provided to his wife for her personal use were limited to the duration of the marriage and save for those expressly declared to be gifts, fell to be returned upon its dissolution.

The case of Quaico v. Fosu (1965) ameliorated the condition of widows. There, the court found, for the first time, that under Akan customary law, a widow, while she remained unmarried, had a proprietary interest equivalent to a determinable life tenancy in her deceased husband's property. Further, and perhaps more importantly, she did not have to live in the property; she could rent it out and enjoy the rental income therefrom. While the family acquired title to the late husband's estate, it was subject to the life interest of his children and the occupational rights of the widow. Quaico v. Fosu not only gave widows, at last, a proprietary right, albeit only a non-heritable, inalienable, potentially temporary one; it also provided a potential source of income for the widow. As for ex-wives, they remained firmly under the Quartey v. Martey regime until the doctrine of substantial contribution was adopted by the courts.

\section{Substantial contribution doctrine}

In the 1970s, the courts introduced the doctrine of substantial contribution, which deemed a wife to have acquired a proprietary interest in property if she had contributed to its acquisition (financially or in-kind) to a degree exceeding the duty of wifely assistance contemplated by customary law. The scope of this interest, however, was to be determined by the court on a case-by-case basis. In Yeboah v. Yeboah (1974), where the doctrine was first espoused, the wife had, at her own expense, flown repeatedly to Ghana from their London residence to supervise the construction of the property in dispute and paid the costs of structural changes thereto. The court held that the wife was a joint owner of the house and further, that the conduct of the parties prior to, during, and subsequent to the acquisition of the property displayed an intention to own the matrimonial home jointly.

What the principle of substantial contribution entailed was elucidated by Abebreseh v. Kaah (1976), Clerk v. Clerk (1981), and Achiampong v. Achiampong 
(1983). In Abebreseh, the court found that part payment for the land and sole support of the family during the construction period amounted to a "substantial contribution." In Clerk, the court stated that it would, or at least could, hold the overwhelming role in family life played by a stay-at-home wife and mother as a substantial contribution; but only if the wife, having had the option of a career, had forfeited it to take care of the home needs of the family. Achiampong added the rule that the substantial contribution could be established by proving either an agreement between the couple giving the wife some beneficial interest in the matrimonial home, or the wife's direct financial improvements, renovation, or extensions to the property, or that she had applied her income for the family upkeep, thereby financially enabling the husband to acquire the property in dispute.

Substantial contribution continued as the guiding principle of a wife's rights in marital property acquired until 1993, when the Fourth Republic began. But it had unclear thresholds, and each judge relied on their own estimation of what acts exceeded the Quartey v. Martey standard. In some cases, contributions that were held not to be insubstantial were nonetheless not held to be enough to convey an interest in the property to the wife; for example, paying in part for and personally supervising the construction of the property (Abobor v. Abobor, 1987) and paying all household bills and the children's school fees to enable the husband to devote his earnings to the property (Otoo v Otoo, 1984, Odoteye v. Odoteye, 1984-86). In others, contributions of the same kind and in some cases to an even lesser extent were held to suffice (Anang v. Tagoe, 1989-90, Domfe v. Adu, 1986). The case law was thus very inconsistent.

\section{Statute law}

The three pieces of legislation that had the greatest impact on the fortunes of wives prior to the birth of the 1992 constitution are $\$ 48$ of the Marriages Act 1884-1985,2 (Cap 127), the Matrimonial Causes Act, 1971 (Act 367), and the Intestate Succession Act, 1985 (PNDCL 111). All three created rather complex legal regimes, an exhaustive overview of which is beyond the scope of the present chapter. It is important to note, however, that Cap 127 created monogamous unions, and, by its $\S 48$, gave the widow acknowledged under it a third of the husband's estate. By creating the possibility of a man supporting his exwife financially, Act 367 seemingly reversed the customary law rule in Ayer $v$. Kumordzi. But it did not apply automatically to all forms of marriage in Ghana. ${ }^{3}$ Even among those to which it applied, it operated to reverse the rule only in "deserving" cases. This subjective standard led to more inconsistency. In Beckley $v$ Beckley (1974), the court made an order of maintenance in favor of the wife. By contrast, in Happee $v$ Happee (1974), the wife was awarded a lump-sum payment but, being held to have been a poor example of a wife, was not granted maintenance. Nevertheless, the impact of Act 367 must not be under-appreciated. For, although it did not have much of an impact on women's property rights, it did, practically speaking, improve their daily economic circumstances by making it 
possible for them to receive lump-sum settlements ${ }^{4}$ or periodic financial support for themselves and/or their children. ${ }^{5}$ PNDCL 111 gave widows a tangible proprietary interest in their husband's estate. But the impractical mandatory apportionment made sale of the property inevitable, and being insubstantial, particularly in polygamous unions, ${ }^{6}$ the widow's portion was hardly ever sufficient (MensaBonsu, 1994).

\section{Equity and/or the judge's own conscience}

Writing in 1972, Daniels, noted that bill-paying wives had become so common that the courts had shaken off the constraints imposed on them by the strict doctrine of customary law (Daniels, 1972). But, absent clear legislative guidance, these equity-based decisions only compounded the deep inconsistency in the case law. In Deborah Takyiwa v. Kweku Adu (1971), a customary law wife was awarded half the farm she had jointly cultivated with her husband on her own land. Would she have been awarded half the farm if it had been jointly cultivated on his land? It is doubtful. Indeed, in Owusu v. Nyarko (1980), decided nine years later, the Quartey v. Martey position was reiterated.

In Bulley-Neequaye v. Acolatse (1969), and also in Reindorf alias Sacker v. Reindorf (1974), property bought by a wife in her husband's name was found by the court to be held in trust for her. In Domfe v. Adu (1986), the court found that the respondent having contributed the initial working capital, and having worked jointly to establish the business, the husband, in whose sole name the business was registered, held it and the profits in trust for himself and his wife. A trend clearly emerges from these cases. Only where the wife had purchased the property or had held the financial power that culminated in the property acquisition were the pre-1992 courts unhesitating in granting a proprietary interest to the wife. Wives who could not prove financially quantifiable contributions did not find the courts so protective.

In sum, prior to the 1992 constitution, Ghana's legal regime on property distribution upon the dissolution or termination of marriage was not exceptionally kind to wives. Though the initial starkness of their position under customary law had been somewhat ameliorated under the substantial contribution doctrine, statutory interventions, and equity, the situation was still far from ideal.

\section{Property rights of wives after the 1992 constitution}

Since January 1993, the 1992 constitution has been the fundamental law in Ghana and has amended all legal regimes to remove any inconsistency with itself. For clarity, we reproduce Article 22, the relevant provision for our purposes.

\section{Article 22}

1) A spouse shall not be deprived of a reasonable provision out of the estate of a spouse whether or not the spouse died having made a will 
2) Parliament shall, as soon as practicable after the coming into force of this constitution, enact legislation regulating the property rights of spouses

3) With a view to achieving the full realization of the rights referred to in clause (2) of this article

(a) spouses shall have equal access to property jointly acquired during marriage

(b) assets which are jointly acquired during marriage shall be distributed equitably between the spouses upon dissolution of the marriage

While the language of the provision is gender neutral, its genesis is not. Article 22 originally appeared under the section titled "women's rights" in the proposals upon which the Constitution was drafted (Government of Ghana, 1991). The section's preamble acknowledges the "great sorrow and distress" that the then state of the law caused widows and recommended that it be changed permanently through constitutional entrenchment (Government of Ghana, 1991).

In this section, we study a number of important decisions to answer the research questions. We ascertain whether judicial outcomes have truly improved for women since the 1992 Constitution took over the regulation of spousal property rights. We also evaluate whether the rhetoric of judicial lawmaking in fact aligns with the 1992 Constitution. This is not an exhaustive review of every case that has been decided under the Constitution. Rather, it is an evaluation based on a group of cases, which together demonstrate the potential viewpoints from which Article 22 could be interpreted.

\section{Substantive judicial outcomes}

Judicial outcomes have generally been better for wives since the coming into force of the 1992 constitution. In a number of important cases, the court has held that the wife was entitled to a share of the matrimonial estate. The interest awarded her has ranged from one-third to half of the matrimonial estate. It is worth noting that in all those cases, the wife was held to have made a substantial and pecuniary contribution to its acquisition. Still, this is quite an improvement on the Quartey v. Martey regime, under which her contribution, regardless of its magnitude or proof, entitled her to nothing.

In another line of cases, the court has, while pronouncing a significant settlement figure, refused to treat the relevant properties as jointly owned at all. In all those cases, too, that decision turned on the wife not having made a substantial financial contribution to their acquisition. This second line of cases shows that the court does not, or has not yet begun to, fully match its rhetoric to its decisions. For though it has said more than once that it is willing to consider non-quantifiable contributions to the family life as a contribution to the family asset portfolio, when this has been all that the applicant relied on, the court has not yet found that a non-pecuniary contribution created a proprietary interest. Nevertheless, it is a credit to the courts that post 1992, they have been more open to viewing such actions as potentially entitling wives to some interest in marital property. And it must not be understated how much better wives in such 
a position have fared post 1993 than their counterparts under the Quartey $v$. Martey regime did.

The circumstances of the cases and the profiles of the women who bring these cases have not changed much. In the post-1992 cases, the partner claiming is still more frequently the one with significantly less earning power. In Quartson (2012), the claimant was a housewife, while her husband was a sailor. In Katey (2016), she was a beautician; he was a geodetic engineer. In Arthur (2013), the wife was a housewife; the husband was an international footballer. The applicant in In Re George Ntim (2012) was primarily a subsistence farmer. In these cases, the contribution proved by the wives was largely of domestic services rendered by them. The cases align with the findings of sociological studies: economic inequality of spouses continues to be a feature of Ghanaian marriages, and women are more frequently the vulnerable partner (Deere et al., 2013). One new development is the phenomenon of the man as a plaintiff/petitioner seeking an interest in the property, as in the case of Mensah (1993). But this remains rare. Again, this confirms the data that women are still largely lower than men on the employment/economic hierarchy. That, in turn, implies that female spouses are more dependent than male spouses on judicial largesse in determining their entitlement to the property.

Like the pre-1992 wives, these post-1992 wives did not act to ensure that their joint ownership was reflected in the title documents, though they were usually aware of the disputed properties at the time of their acquisition. Admittedly, in a good number of cases, the wife was so unevenly matched with her husband economically that it was not necessarily an option for her to get her name onto the paperwork. This was the case in Arthur, Katey, and In Re George Ntim. But this is not the scenario in other cases. Gladys Mensah was an equal partner and manager of the business they established jointly. She collected monies and kept the accounts. Yet, she let her husband put 4 houses totaling 16 bedrooms, several plots of vacant land, a 20-foot container, and several cars in his name only. In Quartson, the sailor-husband was away for long stretches of time; several years in one instance. The wife, with the money he remitted to her, purchased materials and supervised the construction of the matrimonial home to its completion. She also claimed to have acted as a director in a jointly run company, yet her name was conspicuously missing from the title documents, and the court found from the evidence a discernible intention in the absent partner to hold the house as sole owner. The wife in Tabury (2013) was just as industrious and as involved in the business that made them rich as Gladys Mensah. Yet, she too let her husband vest all properties acquired with the proceeds from their joint enterprise in his name. It cannot be said, therefore, that the vulnerability of wives in respect of the matrimonial property is entirely a function of economic inequality. There are clearly social and cultural factors at play that are beyond the reach of the law that must be addressed in the larger society. In particular, the cultural narratives on women, personal responsibility, and property must be rethought.

Where the husband is the petitioner in respect of the settlement of matrimonial property, two outcome trends are visible. In one line of cases, the husband 
is petitioning to be named sole owner of the property to which he held the title and which he also built or helped to build (Verdose $v$ Verdose-Kuranchie, 2009 and Esseku v. Inkoom, 2013). The wives, inevitably, failed in a similar counterclaim. However, where the wife was the owner of the land and constructed the house either solely or with minimal participation of the husband (as occurred in Kwawukume, 2009, Owusu, 2011, and Nanor, 2018), the wives succeeded in holding on to their property as sole owners. These cases are far away from the injustice that Quartey v. Martey spawned. But they remain a small minority.

The final observation we make about the outcomes for wives in the Fourth Republic is this: while more wives have got higher percentages of the matrimonial property, the situation is not as heartening as it may appear at first glance. This is because now, as then, such wives often face a great challenge of providing proof of contribution, especially in respect of property other than the matrimonial home. Thus, the court might award $50 \%$ of the matrimonial property to her. But more than $50 \%$ of the assets under contention may remain completely outside the definition of matrimonial property. Given the similarity between fact trends of pre- and post-1992 cases, a wife's chance of profiting from the asset portfolio of the couple beyond just the matrimonial home is still minimal. On the outcomes front, therefore, it is fair to say that we are almost as far away from the constitutional ideal as we are from the Quartey $v$ Martey days. That means the journey is far from over.

\section{Rhetoric}

The 1992 constitution is barely mentioned in the earliest cases of the Fourth Republic. Rather, equity and the substantial contribution doctrine are the principal points around which the decisions are made. The rhetoric changed noticeably in Mensah v. Mensah (1993), where the 1992 constitution made its first, albeit peripheral, appearance as a guiding principle in a matter of property distribution between spouses. The court held that in the absence of clear equities in matrimonial property, the court would treat equality as equity. But even with marginal mention, the role the constitutional terminology played in pulling out the entrenched roots of customary law and replacing it with constitutional compliance should not be overlooked. In Boafo v Boafo (2005), the court held that the Mensah rule of "equality is equity" is not what it called "a blanket" rule applying blindly and in all cases. Instead, the equities of each case were to be considered. The court then reintroduced the language of the substantial contribution doctrine but collocated it under Article 22 and the "equality is equity" rubric (Barnes, forthcoming, 2020) ${ }^{7}$; a development discussed more fully later on in this chapter.

The constitutional rhetoric finally comes into its own in Gladys Mensah v. Stephen Mensah (2012), where the Supreme Court not only dwelt extensively on Articles 22 and $35^{8}$ but expressly pronounced the substantial doctrine rule unconstitutional. Quartson v. Quartson is alone in this line of cases. Although, again, the outcome is not undesirable, the language is puzzling and disappointing, 
because the Supreme Court oddly ascribed the birth of the substantial contribution rule to Parliament's inaction in respect of its Article 22 obligation to regulate the distribution of marital property upon dissolution or determination of marriage. It is important to note that the court expressly spoke of substantial financial contribution. It then, confusingly, held that the Court of Appeal was wrong to hold that the wife had no interest in the matrimonial home and yet refused to give her a share therein. Fortunately, Arthur v. Arthur (2013) set things right again. In that case, the court found the wife's performance of her housekeeping duties and as the personal driver (to her husband) sufficient to amount to such substantial contribution as to grant the wife an interest in the matrimonial home. This position has been followed in a number of cases, including Kofi Tabury. Arthur further established the assumption, albeit rebuttable, that property acquired during the subsistence of the marriage is marital property and therefore should be shared between the parties. The court found that to hold otherwise, as the Court of Appeal had in the same case, would be inconsistent with the Constitution. However, this is not to be taken as inconsistent with the constitutional right to own property alone. The Supreme Court indicated that some categories of properties could be excluded from this presumption, as determined on a case-by-case basis.

In the second line of cases discussed in the preceding section, the court once again relied heavily on the constitution to reach its decision. Although the women in these cases did not succeed in their requests, the language of the judicial decision-making is consistent with that of the first line of cases, in which the women succeeded at least in part. In Fynn, for example, the meaning of the relevant constitutional provisions was discussed quite extensively and was central to the decision. Additionally, the court discussed Article 18 and concluded that the property in question was not jointly owned. Electroland v Adomako (2019) saw an interpleader by a husband succeed on the ground that the property sought to be attached was his personal property, not jointly owned property, and as such could not be used in satisfaction of his wife's business debts.

It is interesting to note that in both lines of cases, the courts continue to search for proof of contribution or the intention of the parties at the time of acquisition as discernible from the couple's conduct at the time. In Gladys Mensah, the court makes a radical move away from the substantial contribution doctrine and reframes the principles within the language of the constitution, thereby extending and strengthening the equality principle. To go contrary to this new exposition of the law was no longer merely a departure from equitable principles. It was, per Arthur, in contravention of the constitution. In the decade since Gladys Mensah, the court has reiterated its position that a substantial, and specifically a financial, contribution is not required to create a proprietary interest in matrimonial property. Yet, there remains a marked insistence on the contribution (the desirability of which we discuss in subsequent paragraphs) that belies Dotse JSC's conviction that the post-1992 precedents had "sounded the death knell of the substantial contribution doctrine" (Gladys Mensah v. Stephen Mensah, 2012). The early post-1992 decisions give no real explanation of why the court could not 
seem to get beyond proof of contribution even as it waxed eloquent about equality and equity. In the later cases, however, the courts have attempted to explain both why they accept housekeeping as contribution and why they still require proof of contribution. In these discussions, the Constitution and its dictates have dominated the dialogue and the decision.

The foregoing discussion has reviewed and reflected on the case law on the property rights of wives. It has examined the trends in outcomes to know whether wives are faring better in the Fourth Republic and if so, how much. The discussion has also assessed the rhetoric of judicial reasoning to determine its commensurability with the outcomes. Our discussion leads us to answer both the research questions posed earlier in the affirmative. Yes, the likelihood that a widow or ex-wife will be sent away empty-handed has reduced considerably. Yes, the rhetoric on judicial equity for spousal rights has become increasingly centered on the Constitution. In spite of some lingering challenges, there has been a marked movement in the rhetoric toward recognizing the rights of wives to marital property irrespective of financial contribution, or indeed, any contribution. But the outcomes have not always been as consistent as one would expect, nor have they always matched the rhetoric. Nevertheless, from the preceding discussion, it is beyond debate that the 1992 constitution has had a palpable and positive impact on the fortunes of wives when a marital property falls to be distributed.

\section{Outcomes versus rhetoric: Where are we now?}

We have seen that the outcomes for women have improved in actions for the distribution of matrimonial property. We have also noted how the rhetoric has evolved from the harsh rule of Quartey v. Martey through the substantial contribution doctrine to the present position, touted as the "Jurisprudence of Equality," which, according to the courts, aligns with the purposes of the 1992 constitution. This section evaluates the truth of that assertion. We examine Nanor v. Nanor and Electroland v. Adomako (supra) to assess the validity of the courts' parameters when called to determine whether the matrimonial property is jointly owned. While conceding their necessity, we draw attention to the problematic nature of these parameters.

The relevant facts of Nanor are as follows: the husband sought, upon divorce, the matrimonial home, another of his wife's three houses, and a plot of her land. He did not deny that all the property was acquired by his wife with her own funds alone. But he argued that because he had run some of the purchasing errands and had done some amount of the construction supervision, he had contributed to the completion of the matrimonial home and should be granted a half share. In respect of the other properties, his argument was that he had married her under the Marriage Ordinance (Cap 127) and that it was he who introduced his wife to the person who helped her acquire goods on credit to begin her textile business. For those reasons, he invited the court to hold him the owner of half of her wealth. The High Court rightly rejected his arguments. 


\section{Article 22 concerns}

Of interest to this chapter is the court's reasoning for refusing to hold that the matrimonial home was joint property. The court held that being married ipso facto could not create a proprietary interest in each other's assets. The husband's involvement in the construction of the matrimonial home had been no more than what his duty to care for his partner entailed. Therefore, it did not create title in him. This decision, on the facts presently given, is not very different from Clerk, where the court ruled that the acts of the wife, which were pleaded as giving rise to entitlement in the marital property, were merely what was expected of a "good wife," or indeed Ribeiro, ${ }^{9}$ where the minority argued that the bare domestic services rendered by the wife did not give her rights to her husband's property. Yet, it is hard to say it was untenable. If it is not, then in principle, neither were the two earlier cases. In that case, Mensah and Arthur are by implication wrong.

But there are additional facts to Nanor that help shape the discussion. The husband had essentially been supported by his wife for almost the entirety of their marriage. She had borne all the bills of their joint life and family. The husband even admitted that all sums he had expended personally on the matrimonial home had been reimbursed to him by his wife at his instance. Nor did he claim to have borne the larger share of the domestic or child-raising duties. His wife's success was in spite of, rather than because of, him. It is clear, then, that the husband of the marriage had not conducted himself in such a way that it was reasonable to hold him co-owner of his wife's property. The point is this: the requirement of contribution to the acquisition of the property is not unreasonable even in a constitutional era that promotes spousal rights to the property. By necessary implication, then, it is possible, even if not easy, to determine the facts of each case: whether the conduct of a spouse exceeds what is a reasonable minimum and attains a level that gives the other spouse an advantage or opportunity to acquire assets.

Even so, there are two opposite but equally grave concerns with the substantial non-pecuniary contribution requirement. On the one hand, given Ghana's history of cultural and customary law bias against wives' property interests, there is a high risk of retrogression to the old forms if the terminology of the new era resembles or even echoes the terminology of the old days. It makes it easier for the old rules to creep into the workings of the new ones, thereby eroding all the benefits of the 1992 constitutional regime. For example, in a significant number of the cases discussed, the court sought or somehow managed to quantify the nonpecuniary contributions proved by a party. The judges' discussions and assessments of the wife's claim of financial contribution would not, in some instances, sit awkwardly in Abebereseh or Yeboah.

But on the other hand, without further clarification on where parenting and home management, as a duty of the couple, end, and where title-creating housekeeping and parenting begin, the court appears to be saying that no duties of parenting or cohabiting exist in the absence of property. We illustrate with Quartson, where the wife pleaded her housekeeping and childrearing 
as contribution sufficient to create a title in her. The court found that Mrs. Quartson's assumption of her husband's parental duties in addition to her own amounted to a contribution to its acquisition. For the purposes of this chapter, and, without endorsing the traditional view of gender roles, we shall assume, as the case law does, that in a Ghanaian marriage, the woman's role is to keep the house and raise the children, while the man's is to pay the bills. On that premise, it is tempting to think that Mrs. Quartson succeeded because she was playing the other parent's role in addition to her own. But as we demonstrate, deeper engagement with the facts will show this reasoning to be only superficially attractive.

First, if there had been no matrimonial home, would Mrs. Quartson not have cared for the children when her husband failed in doing his part? If she would have, then the court ought to have been clearer as to what extent her care of her children differed from what she would have given them if there had been no property. This distinction must be discernible, it is argued, for the line between parenting/partnering simpliciter, and parenting/partnering as the root of title, not to be arbitrary. Mrs. Quartson rose to the occasion when she was made a single parent. The paradox here is that it does not mean necessarily that she contributed to his assets. But it also does not necessarily mean that she did not. The court should have engaged more fully with the facts to explain how they met the threshold of contribution. For example, what if a housewife pays school fees for a long period of financial difficulty and then is reimbursed by the husband and after that reimbursement, he acquires properties? Do the school fees years count as her contribution to those houses or not?

The effort required for a housewife to step into her husband's shoes is significantly greater than what would be required for the managing director of a transnational bank to do the same. It seems unfair to undervalue the housewife's effort simply because it was reimbursed. It also seems unfair to say the wife, who is the managing director, had no interest in her matrimonial home because stepping into her errant husband's shoes had been easier for her. Moreover, the court should not appear to be relieving parents whose union has acquired no property from the ordinary obligations of parenthood. It is concerning that Mensah and, especially, Arthur do not draw the line clearly between partner/ parent duties simpliciter and partner/parent acts creating title in the matrimonial property.

We do not by this analysis either endorse or reject the rightness of the view that marriage should ipso facto render all assets of both parties jointly held. That rule exists in several countries on other continents, and as with all things, has its merits and demerits. However, an evaluation of these is, for want of space, beyond the scope of this chapter. What we seek to do by this analysis is to assess whether what the court has been saying and doing is indeed what the 1992 constitution of Ghana requires it to do. Our answer is that the court must, with the greatest respect, reflect on and clarify where the ceiling of wifely/husbandly duty ends and where the floor of property-creating duty begins. Otherwise, improved outcomes notwithstanding, it cannot claim to have aligned the legal order with the constitutional purposes for which Article 22 was enacted. 


\section{Article 18 concerns}

In Fynn, the Supreme Court first grappled with the effect of their broad interpretation of Article 22 on Article 18. In that case, a husband sold a store, and his wife sought to have the sale overturned on the grounds that the store was jointly owned property and the sale was without her knowledge and consent. The court held that parties within a union retained their Article 18 right to own property alone. As such, the property of one spouse did not automatically become the property of the couple, and the spouse retained the power to dispose of such property unilaterally. The court refused, therefore, to overturn the sale.

Fynn was applied in Electroland $v$ Adomako (supra). The facts of that case and the court's reasoning are helpful aids to understanding the import of the Mensah rule as it would have operated had the caveats not tempered it. In Electroland, where the husband successfully resisted the attachment of his house in the satisfaction of a judgment debt against his wife, the court discussed extensively the practical implications of Mensah for Article 22 and concluded that the right to equitable distribution of marital property did not arise while the marriage subsisted. The court held further that absent proof of contribution to its acquisition, property did not become jointly held only because of the continued subsistence of the marriage. To hold otherwise would have amounted to removing the right of a married person to hold property alone under Article 18, and that would, of course, be unconstitutional.

Again, premised on the model of the Ghanaian marriage as described earlier, it is immediately evident that there is tension between Articles 18 and 22. As noted earlier, to hold, as the court did in Mensah and Arthur, that housekeeping and childrearing duties suffice as contribution to property acquisition is to hold that all property acquired during marriage is marital property unless one spouse is a bad partner. Indeed, the court held it to be a rebuttable presumption in Arthur.

This, in turn, means that no party in a union may dispose of their property alone. While it could be argued that it is ideal for a married couple to make decisions about their individual property jointly, it can hardly be argued that the law should compel them to. Such a legal state of affairs would, in addition to discouraging citizens from legally combining their estates, have the most deleterious effect on commerce. In the Fynn case, the third party had diligently conducted her enquiries into the ownership of the store before proceeding with the sale. To reverse it because of an undiscoverable third-party interest would have been inequitable and would have set a poor precedent for the sanctity of commercial transactions.

Be that as it may, the question of what the Constitution requires the courts to do is easily answered in respect of Article 18. It requires the courts to uphold and protect the sole ownership of self-acquired property. To do this, the courts have had to introduce some limits on their own jurisprudence under Article 22 in order to prevent a headlong collision of the two constitutional provisions. Seen in that light, the limitations on the Mensah and Arthur principle are not unreasonable, even if, as discussed, they may be problematic. 


\section{Conclusion}

This chapter has been driven by three critical inquiries. First, we juxtaposed the landmark cases decided before the 1992 constitution entered into force with those decided thereafter to determine whether outcomes have truly improved for women since the 1992 constitution took over the regulation of spousal property rights in Ghana. We then examined the rhetoric of the post-1992 jurisprudence to ascertain whether the dictates of the 1992 Constitution have attained a centripetal role in judicial reasoning and decision-making in this sphere of the law. Finally, we tested the constitutional compliance of the judicial reasoning in the jurisprudence by examining its implicit and explicit ramifications. We found that the language of judicial reasoning was undoubtedly in consonance with the Constitution. The answer to the question on outcomes was more complicated, being at once yes and no. While fewer women are walking away empty-handed from the fruits of their efforts, they are not necessarily getting the full value of their labor. We conclude that the court needs to further illuminate both its rules under Article 22 and the limitations it has put on its interpretation. We note that the profiles of the wives indicate clearly that there are problems of socialization that need to be tackled if Article 22 is to be fully realized; there is only so much the law can do. Parliament's deplorable failure to enact the legislation envisioned in Article 22 has ensured that the court's journey toward constitutional implementation will be a muddled, stumbling journey. But even so, it is on its way. And, in spite of the rough terrain, it is a worthy path the court is charting.

\section{Notes}

1 Ollennu based his decision on Okwabi v. Adonu (2 W.A.L.R 268), which decided that a child did not become co-owner of property acquired from the joint industry of the child and the father. The case had nothing to do with marriage, yet the learned judge found that the principle could apply to property acquired by the husband from the proceeds of joint efforts of himself and his wife.

2 Formerly known as the Marriage Ordinance.

3 Act 367 applies to marriages other than monogamous ones only on application by a party to the marriage. See Section 41.

4 e.g., Clerk v Clerk (n 13), Ribeiro v. Ribeiro (n 14), Gyang v. Gyang (Accra H.C., Jan. 30, 1987), Okang v. Okang, (Accra H.C., Sept. 3, 1985).

5 e.g., Abobor v. Abobor (n 12), Ahmed v. Ahmed (Accra H.C., Oct. 4, 1988), Addai v. Addai (Accra H.C., Sept. 16, 1983).

6 Further, HJAN Mensa-Bonsu has argued that the conflation of the widows' and children's interests in a polygamous society has eroded the benefits of the Act when (as is commonly the case) there are multiple spouses or children of multiple mothers. See Henrietta Mensa-Bonsu, "The Intestate Succession Law of Ghana: Practical Problems in Application" (1994) 8 Yearbook of African Law, 105.

7 Some writers have criticized the judgment as reintroducing the language of substantial contribution - and by extension, its challenges—into the post-1992 era. See M.Y.A Barnes, "Equality is Equity...or is it? A critical Examination of the Equality Principle in Distribution of Marital Property." In C. Dowuona-Hammond et al, Ghana@60: Mobilising the Law for Ghana's Future (Wildy, Simmonds and Hill, forthcoming, 2020). 


\section{Yaa Mensa-Bonsu and A.S. Mensa-Bonsu}

8 Which allows the court to enforce any other internationally recognized human rights not expressly provided for in the Constitution.

9 This was an application for financial provision under the Matrimonial Causes Act. However, the court discussed the point and intimated that it would have been willing to grant her a proprietary interest had she applied for one.

\section{Constitutions and legislation}

Ghana Constitution, 1992

Intestate Succession Act, 1985 (PNDCL 111)

Marriage Ordinance (Cap 127)

Matrimonial Causes Act, 1971 (Act 367)

Property Rights of Spouses Bill

Intestate Succession Bill

Lands Bill

\section{Other}

Government of Ghana, Accra Report of the Committee of Experts on draft Proposals for the Constitution, 1991, Assembly Press.

\section{Case law}

Abebreseh v. Kaah [1976] 2 GLR 46-42

Abobor v. Abobor (Accra H.C., Feb. 16, 1987)

Achiampong v. Achiampong [1982-83] GLR 1017-1039

Adom v. Kwarley [1962] 1 GLR 112

Amissah-Abadoo v. Abadoo [1974] GLR 110

Anang v. Tagoe [1989-90] 2 GLR 8

Arthur v. Arthur [2013-2014] SCGLR 543

Ayer v. Kumordzie [1964] GLR 622

Beckley v. Beckley [1974] 1 GLR 393

Boafo v. Boafo [2005-2006] 705

Bulley-Neequaye v. Acolatse (1969) C.C. 51

Clerk v. Clerk [1981] GLR 583

Deborah Takyiwa v Kweku Adu, Unreported judgment of the High Court (Sunvani Suit No. L.C. 7/66) May 18,1971

Domfe v. Adu [1986] 1 GLR 653

Happee v. Happee [1974] 2 GLR 186

Electroland v. Adomako Unreported, decided April 22, 2009 HC

Fynn v. Fynn [2013-2014] 1 SCGLR 727

Gyang v. Gyang (Accra H.C., Jan. 30, 1987)

In re George Ntim: Marfoa v. Agyeiwaa, unreported suit no J2/42/2012 SC

In re Kofi Antubam (decd); Quaico v. Fosu [1965] GLR 138

Kofi Tabury v. Adwoa Yeboaba unreported, decided January 24,2013 CA

Kwawukume v. Kwawukume unreported, July 30, 2009 (CA)

Jonas v. Ofori (Accra H.C., Jan II 1988) 